\title{
PERBEDAAN LATIHAN LOMPAT GAWANG BERTAHAP DAN LOMPAT GAWANG TETAP TERHADAP KEMAMPUAN LOMPAT JAUH GAYA JONGKOK PADA SISWA PUTRA USIA 11 - 12 TAHUN DI MI MUHAMMADIYAH TINGGARJAYA BANYUMAS JAWA TENGAH 2021
}

\author{
Marwanto Ari Sujatmiko a, Slamet Santoso M.Pd ${ }^{b}$, Rima Febrianti, S.Pd., M.Pd c \\ abc Physical Education, Universitas Tunas Pembangunan Surakarta, Surakarta, Indonesia. \\ email:amarwaantoari74@gmail.com
}

\begin{tabular}{l}
\hline I N F O A R T I K E L \\
\hline Sejarah artikel: \\
Menerima 1Juli 2021 \\
Revisi 21 Juli 2021 \\
Diterima 22 \\
Online 30 Juli 2021 \\
\hline Kata kunci: \\
Lompat gawang bertahap, \\
Lompat gawang tetap, \\
Lompat jauh gaya jongkok
\end{tabular}

Keywords: Gradual Goal Jump, Fixed Goal Jump, Long Jump Squat Style

\begin{abstract}
ABSTRAK
Penelitian ini bertujuan untuk megetahui perbedaan latihan lompat gawang bertahap dan lompat gawang tetap terhadap kemampuan lompat jauh gaya jongkok siswa putra usia 11-12 tahun di MI Muhammadiyah Tinggarjaya Banyumas Jawa Tengah 2021. Penelitian ini merupakan penelitian kuantitatif dengan metode Eksperimen pretestposttest. Penelitian dilaksanakan dengan tes awal (pretest) dan diberikan perlakuan (treatment) dan diakhiri dengan tes akhir (posttest), dilaksanakan untuk mengetahui perbedaan lompat gawang bertahap dan lompat gawang tetap terhadap kemampuan lompat jauh gaya jongkok. Subjek penelitian adalah siswa putra usia 11-12 tahun di MI Muhammadiyah Tinggarjaya Jawa Tengah yang berjumlah 30 orang. Teknik pengumpulan data adalah dilakukan tes pengukuran lompat jauh gaya jongkok dengan lompat jauh. Analisis data menggunakan uji prasyarat analisis data (uji normalitas dan uji homogenitas) dan uji perbedaan. Hasil penelitian menunjukkan bahwa terdapat pengaruh perbedaan hasil latihan lompat gawang bertahap dan lompat gawang tetap terhadap kemampuan lompat jauh gaya jongkok pada siswa putra usia 11 - 12 tahun di MI Muhammadiyah Tinggarjaya Banyumas Jawa Tengah 2021, karena nilai t yang diperoleh sebesar 6,076 lebih besar dari $\mathrm{t}$ tabel 2,048 dan angka signifikan 0,000 $<0,05$ sehingga ada perbedaan signifikan nilai tingkat kemampuan lompat jauh gaya jongkok antara kedua kelompok setelah diberikan perlakuan. Hal ini menunjukkan dari hasil analisis latihan lompat gawang bertahap dan lompat gawang tetap terhadap kemampuan lompat jauh gaya jongkok mempunyai perbedaan yang signifikan. Presentase rata - rata peningkatan latihan lompat gawang bertahap lebih baik pengaruhnya dari pada lompat gawang tetap, yaitu dengan lompat gawang bertahap peningkatan sebesar $17,5 \%$ dan latihan lompat gawang tetap peningkatan sebesar 7,41\%.
\end{abstract}

\footnotetext{
Style APA dalam mensitasi artikel ini: [Heading sitasi]

Marwanto Ari Sujatmiko (2021). Perbedaan Latihan Lompat Gawang Bertahap dan Lompat Gawang Tetap Terhadap Kemampuan Lompat Jauh Gaya Jongkok Pada Siswa Putra usia 11 12 Tahun di MI Muhammadiyah Tinggarjaya Banyumas Jawa Tengah
}

(2)

ABSTRACT
The purpose of this study was to determine the differences in
gradual hurdle jump training and fixed hurdles on the squat style long
jump ability of male students aged 11-12 years at MI Muhammadiyah
Tinggarjaya Banyumas, Central Java 2021. This research is a
quantitative study using the pretest - posttest experimental method. The
research was carried out with a pretest and given treatment and ended
with a posttest, which was carried out to determine the difference
between gradual hurdles and fixed hurdles on the squat style long jump
ability. The research subjects were male students aged $11-12$ years at MI


2021. Jurnal Ilmiah Penjas 7 (1) $13-23$
Muhammadiyah Tinggarjaya, Central Java, totaling 30 people. The data collection technique was carried out by measuring the squat-style long jump test with the long jump. Data analysis used the prerequisite test data analysis (normality test and homogeneity test) and difference test. The results showed that there was an effect of differences in the results of gradual hurdle jump training and fixed hurdles on the squat style long jump ability of male students aged 11-12 years at MI Muhammadiyah Tinggarjaya Banyumas Central Java 2021, because the t value obtained was 6.076 greater than $t$ Table 2.048 and a significant value of 0.000 $<0.05$, so there is a significant difference in the value of the squat style long jump ability between the two groups after being given treatment. This shows that from the results of the analysis of gradual hurdle jump training and fixed hurdle jumps, the squat style long jump ability has a significant difference. The average percentage increase in the gradual hurdle jump training had a better effect than fixed hurdles, namely with a $17.5 \%$ gradual increase in hurdles and an increase of $7.41 \%$ in hurdling training.

\section{Pendahuluan}

Dalam (Undang - undang nomor 3 tahun 2005) tentang Sistem Keolahragaan Nasional menyatakan bahwa : Keolahragaan Nasional bertujuan memlihara dan meningkatkan kesehatan dan kebugaran, prestasi, kualitas manusia. Untuk meningkatkan sumber daya manusia, maka pembinaan prestasi olahraga perlu dilakukan dan di gerakan melalui perencanaan dan pelaksanaan yang mantap serta dilaksanakan secara terpadu dan merata di seluruh tanah air. Hal ini bukan saja dilakukan oleh pemerintah, akan tetapi juga perlu di dukung oleh berbagai pihak.

Oleh karena itu pendidikan jasmani merupakan salah satu muatan pendidikan dalam segala jenjang tingkatan pendidikan. Selain untuk keseragaman materi pendidikan, juga merupakan salah satu metode pencapaian sasaran pendidikan atau berusaha mencapai salah satu taraf prestasi tertentu. Hal ini ditandai dengan sering diadakannya kejuaraan atau pertandingan yang mengikut sertakan pelajar dan memperlombakan nomor - nomor cabang olahraga yang di antaranya adalah atletik yang meliputi jalan, lari, lompat, dan lempar.

Atletik itu sendiri merupakan satu cabang olahraga yan termasuk dalam materi pokok dalam pendidikan jasmani. Keberadaan cabang olahraga atletik ini mempunyai peran penting untuk menunjang perkembangan dan pertumbuhan 
gerak anak. Melalui pendidikan jasmani, nomor - nomor cabang olahraga atletik diajarkan kepada siswa, hal ini dimaksudkan agar siswa mengenal dan menguasai macam - macam nomor cabang olahraga atletik. Salah satunya nomor yang akan dikaji dan diteliti yaitu nomor lompat khususnya lompat jauh gaya jongkok.

Sekolah Dasar merupakan pendidikan awal yang dapat digunkan untuk mengembangkan pertumbuhan fisik dan kemampuan gerak siswa. Pada masa pembinaan kemampuan fisik dapat dimulai (Koko Prasetyo, 2016:197). Pada MI Muhammadiyah Tinggarjaya lompat jauh merupakan salah satu materi yang diajarkan dalam pelajaran Pendidikan Jasmani. Berdasarkan kenyataannya, pelaksanaan pendidikan jasmani telah berjalan dengan baik termasuk lompat jauh. Namun sejauh ini kemampuan yang diperoleh siswa masih rendah dan perlu ditingkatkan. Masih rendahnya kemampuan lompat jauh gaya jongkok yang perlu ditelusuri faktor - faktor penyebabnya.

Beberapa faktor penyebabnya kurang baiknya kemampuan lompat jauh para siswa berasal dari power yang belum teratih, selama ini siswa hanya dilatih atau diajarkan tanpa memperhatikan unsur - unsur yang mendukung hasil lompat seperti power. waktu yang tersedia dalam pendidikan jasmani merupakan salah satu faktor yang mempengaruhi pihak guru, sehingga guru tidak dapat melatih dan mengembangkan kondisi fisik yang dapat mendukung pencapaian prestasi lompat jauh. Pada umumnya pemberian materi lompat jauh gaya jongkok hanya terbatas pada pengenalan teknik melompat saja, itupun terkadang waktunya tidak cukup. Kondisi semacam itu tidak memungkinkan untuk mencapai bentuk - bentuk latihan yang dapat mendukung pencapaian kemampuan lompat jauh yang maksimal guna medapatkan hasil yang maksimal.

Upaya untuk meningkatkan kemampuan lompat jauh gaya jongkok dipengaruhi oleh banyak faktor. Kemampuan fisik dan penguasaan teknik melompat yang baik dan benar merupakan faktor yang mempengaruhi pencapaian kemampuan lompat jauh. Fisik dan teknik merupakan dua komponen kyang tidak 
dapat dipisahkan dan saling berkaitan. Hal ini karena, penguasaan teknik yang baik hanya dapat dilakukan apabila memperoleh dukungan kemampuan fisik yang baik pula. Kemampuan fisik yang baik memberikan keuntungan terhadap efisiensi dan efektivitas gerakan, sehingga prestasi dapat tercapai.

Menurut Pandu Kresnapati (2018:136) untuk meningkatkan tenaga kaki (power) akselerasi lari, banyak sekali cara untuk melatihnya, antara lain ; latihan dengan lari gawang, langkah melambung (lari kijang, lompat kelinci, lompat jauh, kombinasi lompat dan melambung melintasi rintangan rendah, berlari dengan lutut tinggi ke depan dan ke belakang, latihan ini dapat meningkatkan kemampuan lompat jauh. Peneliti disini menggunakan latihan dengan lari gawang.

Lompat jauh terdapat tiga gaya yang umum dipergunakan oleh pelompat yaitu gaya jongkok (tuck), gaya menggantung (hang style), dan gaya berjalan di udara (walkin in the air), sesuai dengan pendapat Dikdik Zafar Sidik (2010: 67). Gaya lompat jauh yang paling sederhana untuk diajarkan pada pemula seperti siswa di SD/MI adalah lompat jauh gaya jongkok.

Bentuk latihan yang dapat meningkatkan tolakan pada lompat jauh dengan 2 cara yaitu lari gawang bertahap dan latihan gawang tetap. Latihan ini pada intinya bertujuan untuk memacu dan meragsang tolakan kaki agar kuat sehingga menghasilkan lompatan melambung tinggi. Gerakan dengan gawang adalah melompat di atas serangkaian gawang rendah, cara melakukannya masing masing peserta melompat atau melambung di atas serangkaian gawang yang rendah, tangan digerakan di atas dan paha kaki yang memimpin digerakan ke atas pada setiap lompatan. Latihan - latihan tersebut diberikan kepada anak dengan program latihan memakai beban berat badannya sendiri dan mudah untuk dilakukan. Kedua bentuk latihan tersebut belum diketahui dengan pasti, mana yang lebih efektif dalam meningkatkan hasil belajar lompat jauh gaya jongkok. Untuk mengetahui bentuk latihan yang dapat memberikan pengaruh yang lebih baik, maka perlu dilakukan penelitian. 
MI Muhammadiyah Tinggarjaya Kabupaten Banyumas merupakan yayasan dibawah naungan Majelis Dikdasmen Muhammadiyah. Sekolah itu merupakan sekolah dasar pertama yang mengedepankan ilmu agama. MI Muhammadiyah Tinggarjaya mempunyai 9 ruangan, 1 perpustakaan, dan masjid. Sekolah ini mempunyai halaman yang cukup luas, untuk fasilitas olahraga tedapat lapangan bola voli dan bak lompat jauh.

Berdasarkan observasi yang telah dilakukan pada 15 September 2020, peneliti melakukan observasi wawancara kepada guru penjas. Dari hasil wawancara dapat disimpulkan bahwa pembelajaran pendidikan jasmani yang telah dilaksanakan di MI Muhammadiyah Tinggarjaya terdapat kendala yang dihadapi, antara lain siswa kurang senang terhadap pelajaran atletik, dan beberapa siswa tidak bersungguh sungguh dalam mengikuti pelajaran. Keberadaan siswa merupakan salah satu faktor yang dapat mempengaruhi hasil belajar siswa. Karena siswa yang tidak senang dan kurang sungguh - sungguh dalam mengikuti pelajaran sehingga akan mempengaruhi hasil belajar siswa. Disamping itu juga, pendekatan pembelajaran yang selama ini diterapkan oleh guru belum menunjukan hasil yang optimal. Hal ini dapat dilihat dari ketrampilan gerak dan hasil kemampuan siswa dalam melakukan lompatan yang masih rendah. Kondisi semacam ini harus diperhatikan.

Berdasarkan latar belakang di atas, maka perlu kiranya dilaksanakan penelitian dengan judul "Perbedaan Latihan Lompat Gawang Bertahap dan Lompat Gawang Tetap Terhadap Kemampuan Lompat Jauh Gaya Jongkok Pada Siswa Putra Usia 11 - 12 Tahun di MI Muhammadiyah Tinggarjaya Banyumas Jawa Tengah 2021"

\section{Metode}

Penelitian yang penulis buat merupakan pre - experimental design menurut Sugiyono (2019:111) desain ini dikatakan sebagai pre - eksperimental karena belum eksperimen yang sungguh - sungguh karena masih terdapat variabel luar yang ikut berpengaruh terhadap terbentuknya variabel dependen. Dalam penelitian ini akan dilakukan tes awal pada sampel untuk mengetahui kemampuan awal dari 
sampel penelitian. Kemudian sampel akan dibagi kedalam dua kelompok penelitian dengan menggunakan metode Ordinal. Eko Putro Widiyoko (2015: 24) menyatakan “ordinal merupakan data yang mempunyai jenjang, sehingga responden dapat diurutkan jenjangnya sesuai dengan karakteristik yang ada pada dirinya". Dalam penelitian ini penulis akan membagi data ordinal berdasarkan hasil pretest.

Dalam pengambilan sampel penulis menggunakan teknik purposive sampling.Dimana penulis mengambil data dengan menentukkan kriteria tertentu. Sugiyono (2016:126) sampling purposive adalah teknik penentuan sampel dengan pertimbangan. Sedangkan menurut Ali Maksum (2012:60) purposive sampling adalah sebuah teknik pengambilan sampel yang ciri atau karakteristiknya sudah diketahui lebih dulu berdasarkan ciri atau sifat populasi. Jadi sample dalam penelitian ini adalah seluruh siswa usia 11 - 12 tahun MI Muhammadiyah Tinggarjaya. Data dalam penelitian ini diperoleh melalui tes dan pengukuran. Kemampuan lompat jauh gaya jongkok diperoleh melalui tes dan pengukuran lompat jauh gaya jongkok dari Ismail Marzuki (2018:136).

\section{Hasil dan Pembahasan}

Data hasil penelitian sebagai berikut:

Hasil Tes Awal ( Pre Test)

\begin{tabular}{lllll}
\hline Kelompok & Max & Min & SD & Mean \\
\hline $\begin{array}{l}\text { Senam Aerobik } \\
\text { Low Impact }\end{array}$ & 360 & 280 & 25,34 & 314 \\
Zumba Fitness & 355 & 279 & 24,48 & 310 \\
\hline
\end{tabular}

Tabel 3.1 Hasil Tes Awal ( Pre Test )

Berdasarkan hasil tes awal menunjukan rata - rata lompat jauh siswa kelompok 1 lompat gawang bertahap sebesar 314, nilai tertinggi sebesar 360, nilai terendah 280, dan standar deviasi sebesar 25,34 sedangkan rata - rata untukkelompok 2 lompat gawang tetap sebesar 310, nilai tertinggi 355, nilai terendah 279, dan standar deviasi sebesar 24,48. Dilihat dari nilai rata - rata tersebut menunjukan kedua kelompok memiliki nilai lompat jauh sama.Hasil Tes Akhir (Post Test) 


\begin{tabular}{lllll}
\hline Kelompok & Max & Min & SD & Mean \\
\hline $\begin{array}{l}\text { Senam Aerobik } \\
\text { Low Impact }\end{array}$ & 390 & 345 & 15,64 & 369 \\
Zumba Fitness & 368 & 333 & 13,81 & 312 \\
\hline
\end{tabular}

Tabel 3.2 Hasil Tes Akhir (Post Test)

Berdasarkan hasil tes akhir menunjukan rata - rata lompat jauh siswa kelompok 1 lompat gawang bertahap sebesar 369, nilai tertinggi sebesar 390, nilai terendah 345, dan standar deviasi sebesar 15.64 sedangkan rata - rata untuk kelompok 2 lompat gawang tetap sebesar 333, nilai tertinggi 368, nilai terendah 312, dan standar deviasi sebesar 13.81. Dilihat dari nilai rata - rata tersebut menunjukan kelompok lompat gawang bertahap lebih tinggi nilai lompat jauh dari kelompok lompat gawang tetap, hal ini menunjukan bahwa lompat gawang bertahap lebih efektif untu meningkatkan kemampuan lompat jauh gaya jongkok siswa putra usia 11 - 12 tahun di MI Muhammadiyah Tinggarjaya Banyumas Jawa Tengah Tahun 2021.

\section{Hasil perbedaan}

Tabel 3.3 Rangkuman Hasil Uji Perbedaan Tes Akhir antara Kelompok lompat gawang bertahap dan lompat gawang tetap.

\begin{tabular}{|l|l|l|l|l|}
\hline Kelompok & $\mathrm{N}$ & Mean & Sig & t hitung \\
\hline $\begin{array}{l}\text { Lompat Gawang } \\
\text { Bertahap }\end{array}$ & 15 & 369 & 0,00 & 6,706 \\
\hline $\begin{array}{l}\text { Lompat Gawang } \\
\text { Tetap }\end{array}$ & 15 & 333 & 0,00 & 6,706 \\
\hline
\end{tabular}

Berdasarkan hasil pengujian perbedaan tes akhir dengan $T$ - Test ( independent sampel t test) antara kelompok 1 (lompat gawang bertahap ) dan kelompok 2 (lompat gawang tetap ) diperoleh nilai signifikan 0,00<0,05. Hal ini menunjukkan bahwa 
antara kelompok 1 dan kelompok 2 setelah diberi perlakuan terdapat perbedaan antara latihan lompat gawang bertahap dan lompat gawang tetap terhadap kemampuan lompat jauh gaya jongkok pada siswa putra usia 11 - 12 tahun MI Muhammadiyah Tinggarjaya Banyumas Jawa Tengah Tahun 2021.

\section{Pembahasan}

1. Berdasarkan hasil pengujian perbedaaan yang dilakukan pada tes akhir dengan $T$ - Test (independent sampel $t$ tets) antara kelompok 1 (latihan lompat gawang bertahap) dan kelompok 2 (latihan lompat gawang tetap) diperoleh nilai signifikan sebesar 0,00<0,05, yang berarti ada perbedaan antara latihan lompat gawang bertahap dan latihan lompat gawang tetap terhadap kemampuan lompat jauh gaya jongkok pada siswa putra usia 11 - 12 tahun di MI Muhammadiyah Tinggarjaya Banyumas Jawa Tengah Tahun 2021.

Dari kedua latihan yang dilakukan menggunakan latihan lompat gawang bertahap dan lompat gawang tetap yang sebenarnya memiliki cara latihan yang hampir sama yaitu lintasannya diselingi dengan gawang, dan gawang harus dilewati atau dilompati oleh setiap peserta latihan. Dalam lompat gawang terkandung unsur - unsur seperti sprint, bertolak, melewati gawang, dan mendarat (Muhammad Amin, 2014:12), akan tetapi dari kedua jenis latihan tersebut terdapat perbedaan ukuran tinggi gawang. Pada latihan lompat gawang bertahap menggunakan tinggi gawang yang bervariasi dengan tinggi 30, 40, 50, $60,70 \mathrm{~cm}$, dan pada latihan lompat gawang tetap memiliki tinggi yang tidak berubah - ubah dengan tinggi gawang 50 centimeter selama latihan/treatment. Perbedaan dari latihan tersebut akan menimbulkan pengaruh yang berbeda pula terhadap peningkatkan kemampuan hasil lompat jauh gaya jongkok siswa putra usia 11 - 12 tahun di MI Muhammadiyah Tinggarjaya Banyumas Jawa Tengah Tahun 2021. Dengan demikian hipotesis yang menyatakan ada perbedaan antara latihan lompat gawang bertahap dan lompat gawang tetap terhadap kemampuan hasil lompat jauh gaya jongkok siswa putra usia 11 - 12 tahun MI 
Muhammadiyah Tinggarjaya Banyumas Jawa Tengah Tahun 2021 dapat diterima kebenaranya.

2. Berdasarkan hasil pre test dan post test dari kedua latihan antara lompat gawang bertahap dan lompat gawang tetap menunjukkan bahwa latihan lompat gawang bertahap lebih baik dari pada lompat gawang tetap terhadap kemampuan lompat jauh gaya jongkok pada siswa putra usia 11- 12 tahun di MI Muhammadiyah Tinggarjaya Banyumas Jawa Tengah, berdasarkan hasil presentase peningkatan diperoleh nilai 17, 5\% (lompat gawang bertahap), dan 7,41\% (lompat gawang tetap). Diperoleh nilai rata - rata kelompok lompat gawang bertahap sebesar 314 (pre test) dan 369 (post test), untuk lompat gawang tetap memperoleh nilai rata - rata sebesar 310 (pre test) dan 333 (post test).

Latihan lompat gawang bertahap merupakan latihan yang dimana pada saat latihan gawang yang digunakan berukuran rendah hingga tinggi $(10,20,30,40$, $50,60,70 \mathrm{~cm})$. keunggulan dari latihan lompat gawang bertahap latihannya lebih bervariasi, sehingga siswa saat melakukan latihan tidak cepat bosan, untuk latihan ini sangat cocok untuk pemula karena lebih efektif untuk meningkatan tolakan pada saat lompat jauh gaya jongkok. Sedangkan kekurangan lompat gawang bertahap tidak cocok untuk siswa yang mempunyai lompatan tinggi dikarenakan beban yang diperlukan tidak sesuai. Sedangkan latihan lompat gawang tetap adalah kemampuan untuk melakukan suatu lompatan yang dilakukan dengan menggunakan alat bantu berupa gawang yang berukuran tinggi 50 centimeter dengan panjang palang 100 centimeter (Nurkadri, 2019:56). Untuk lompat gawang tetap mudah dilakukan untuk pemula karena tinggi gawang yang sama pada setiap latihan. Sedangkan kekurangan lompat gawang tetap yaitu latihan yang terlalu monoton membuat siswa bosan selama latihan. Kedua latihan tersebut memiliki kesamaan yaitu latihan yang berguna untuk menguatkan tolakan dan meningkatkan hasil lompatan pada lompat jauh gaya jongkok. 
Dari penjelasan diatas dapat disimpulkan bahwa latihan lompat gawang bertahap lebih efektif diterapkan untuk meningkatkan hasil lompat jauh pada siswa, Selain itu dapat meningkatkan kegembiraan dan tidak mengalami kejenuhan ketika latihan serta membuat latihan menjadi tidak monoton

\section{Simpulan}

Berdasarkan hasil penelitian dan analisis data yang telah dilakukan, dapat diambil kesimpulan sebagai berikut :

1. Terdapat perbedaan hasil lompat jauh antara latihan lompat gawang bertahap dan latihan lompat gawang tetap terhadap kemampuan lompat jauh gaya jongkok siswa putra usia 11 - 12 tahun di MI Muhammadiyah Tinggarjaya Banyumas Jawa Tengah Tahun 2021 dengan nilai signifikan 0,00<0,05.

2. Pada treatment lompat gawang bertahap lebih baik dibandingkan treatment lompat gawang tetap terhadap kemampuan lompat jauh gaya jongkok pada siswa putra usia 11 - 12 tahun di MI Muhamadiyah Tinggarjaya Banyumas Jawa Tengah Tahun 2021. Presentase peningkatan treatment lompat gawang bertahap sebesar 17,5\%, dan presentase peningkatan treatment lompat gawang tetap sebesar $7,41 \%$.

\section{Ucapan Terima Kasih}

Karya-karya yang dikirim oleh penulis diakui tetapi direkomendasikan bahwa peninjau yang diputuskan oleh editor memberikan entri berharga ke setiap artikel untuk mempercepat pekerjaan peninjauan karena terbatasnya jumlah peninjau. Reviewer yang direkomendasikan dapat dicantumkan di halaman akhir setelah referensi karena review dilakukan dengan metode double-blind.

\section{Referensi}

Kemenpora. Undang - undang. No.3. Tahun 2005. Sistem Keolahragaan Nasional. Jakarta : Kemenpora 
Kresnapati. Pandu. 2018. Perbedaan Latihan Weighted Squat dan Straddle Jump Terhadap Lompat Jauh Gaya Jongkok Mahasiswa PJKR UPGRIS Angkatan 2017. Vol 4. No 3.

Maksum. Ali. 2012. Metodologi Penelitian Dalam Olahraga. Surabaya : UNESA

Marzuki. Ismail. dkk. 2018. Hubungan Lari Sprint 100 Meter Terhadap Prestasi Lompat Jauh Pada Siswa Putra Kelas V SDK Larastuka 5 Tahun Pelajaran 2017/2018. Jurnal Pendidikan. Vol 3. No 3.

Nurkadri. 2019. Pengaruh Latihan Lompat Gawang dan Latihan Lompat Samping Terhadap Kemampuan Heading Bola Pada Permainan Sepakbola Ditinjau Dari Daya Ledak Otot Tungkai. Jurnal Pendidikan Kepelatiahan Olahraga. Vol 11. No 2.

Prasetyo. Koko. 2016. Penerapan Pendekatan Bermain untuk Meningkatkan Hasil Belajar Lompat Jauh Gaya Jongkok Pada Siswa Kelas 5 SD. Jurnal Scholaria. Vol 6. No 3.

Sidik. Dikdik. Zafar. 2010. Mengajar dan Melatih Atletik. Bandung : Remaja Rosdakarya. Sugiyono. 2019. Metode Penelitian Kuantitatif Kualitatif, dan REDD. Bandung : Alfabeta

Widoyoko. Eko. Putro. 2015. Teknik Penyususnan Instrumen Penelitian. Yogyakarta : Pustaka Pelajar. 